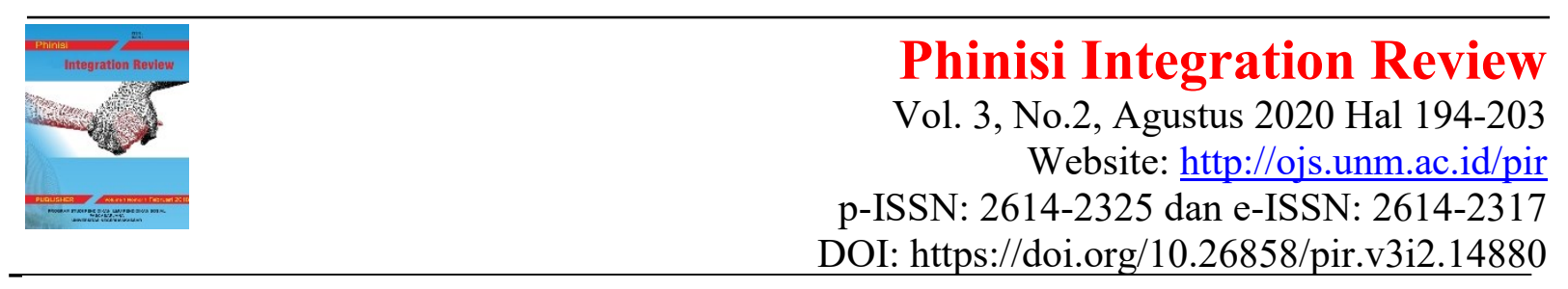

\title{
Integrasi Pendidikan Karakter Pada Mata Pelajaran PPKn Untuk Mengembangkan Kemampuan Mengemukakan Pendapat Siswa
}

\author{
A Wahyuni ${ }^{1}$ Hasnawi Haris ${ }^{2}$ Mustari $^{3}$ \\ Jurusan Pendidikan Hukum dan Kewarganegaraan Pendidikan IPS, Universitas Negeri Makassar \\ Email: a.wahyunihasan@gmail.com
}

\begin{abstract}
Abstrak. Penelitian ini bertujuan untuk mengetahui; (i) upaya yang dilakukan tenaga pendidik untuk mengintegrasikan pendidikan karakter pada mata pelajaran PPKn untuk mengembangkan kemampuan mengemukakan pendapat siswa di SMPN 8 Makassar, (ii) integrasi pendidikan karakter dalam proses pembelajaran PPKn untuk mengembangkan kemampuan mengemukakan pendapat siswa di SMPN 8 Makassar, dan (iii) factor pendukung dan penghambat proses integrasi pendidikan karakter dalam pembelajaran PPKn untuk mengembangkan kemampuan mengemukakan pendapat siswa di SMPN 8 Makassar. Jenis penelitian yang digunakan dalam penelitian ini adalah kualitatif deskriptif. Teknik pengumpulan data yang digunakan dikumpulkan melalui observasi, wawancara, dan dokumentasi, dan dianalisis dengan teknik triangulasi .Hasil penelitian ini menunjukkan bahwa (i) upaya yang dilakukan guru dalam mengembangkan kemampuan mengemukakan pendapat siswa pada mata pelajaran PPKn di SMP Negeri 8 Makassar adalah dengan menerapkan model dan metode pembelajaran yang sesuai dengan materi dimana model tersebut dapat membantu siswa untuk melatih karakter siswa serta meningkatkan keterampilan mengemukakan pendapatnya (ii) menggunakan 3 model pembelajaran yaitu: model Team Assisted Individualization (TAI), metode tanya jawab dan metode konvensional (iii) terdapat faktor pendukung dalam pengintegrasian pendidikan karakter untuk meningkatkan kemampuan mengemukakan pendapat siswa yaitu : (i) Kegiatan yang sudah terprogram dengan baik dalam silabus dan RPP, (ii) sarana dan prasarana yang memadai, (iii) serta dukungan dan kerja sama yang baik antara guru dan orang tua siswa dan faktor penghambat dalam pengintegrasian pendidikan karakter untuk meningkatkan kemampuan mengemukakan pendapat siswa yaitu : (i) kontrol sekolah yang terbatas, (ii) kurangnya pemahaman tentang pendidikan karakter, (iii) keberanian siswa untuk mengemukakan pendapatnya masi kurang, dan (iv) adanya keterbatasan waktu dalam proses pembelajaran.
\end{abstract}

Kata Kunci: Karakter; Kemampuan Mengemukakan Pendapat Siswa

Abstract. This study aims to determine; (i) efforts made by educators to integrate character education in PPKn subjects to develop the ability to express students 'opinions at SMPN 8 Makassar, (ii) integration of character education in the PPKn learning process to develop the ability to express students' opinions at SMPN 8 Makassar, and ( iii) supporting and inhibiting factors in the process of integrating character education in PPKn learning to develop the ability to express students' opinions at SMPN 8 Makassar. This type of research used in this research is descriptive qualitative. Data collection techniques used were collected through observation, interviews, and documentation, and analyzed with triangulation techniques. The results of this study showed that (i) the efforts made by teachers in developing the ability to express students' opinions on PPKn subjects at SMP Negeri 8 Makassar were to apply learning models and methods in accordance with the material where the model can help students to train students' characters and improve their expressing skills (ii) using 3 learning models, namely: the Team Assisted Individualization (TAI) model, question and answer methods and 
conventional models (iii) there supporting factors in integrating character education to improve the ability to express students 'opinions, namely: Activities that are well programmed in the syllabus and lesson plans, adequate facilities and infrastructure, as well as good support and cooperation between teachers and students' parents and inhibiting factors in learning. integrating character education to improve the ability to express students 'opinions, namely: limited school control, lack of understanding of character education, students' courage to express their opinions is still lacking, and there are limited time in the learning process.

Keywords: Character, Ability to Express Students' Opinions

Ini adalah artikel dengan akses terbuka dibawah licenci CC BY-NC-4.0

(https://creativecommons.org/licenses/by-nc/4.0/).

\section{PENDAHULUAN}

Pendidikan merupakan suatu proses pembelajaran pengetahuan, keterampilan, dan kebiasaan sekumpulan manusia yang diwariskan dari satu genereasi ke generasi selanjutnya melalui pengajaran, pelatihan, dan penelitian. Pendidikan menjadi salah satu barometer dalam kemajuan suatu daerah maupun Negara. Hal inilah yang membuat pemerintah terus membuat inovasi untuk memajukan dunia pendidikan yang ada di Indonesia.

Berdasarkan Peraturan Presiden (Perpres) nomor 87 tahun 2017 tentang penguatan pendidikan karakter hadir dengan pertimbangan bahwa dalam rangka mewujudkan bangsa yang berbudaya melalui penguatan nilai-nilai religius, jujur, toleran, disiplin, bekerja keras, kreatif, mandiri, demokratis, rasa ingin tahu, semangant kebangsaan, cinta tanah air, menghargai prestasi, komunikatif, cinta damai, gemar membaca, peduli lingkungan, peduli sosial, dan bertanggung jawab.

Usaha yang dilakukan untuk mewujudkan hal tersebut adalah dengan mendirikan lembaga pendidikan sekolah. Sekolah merupakan lembaga pendidikan formal yang memegang peranan sangat penting dalam meningkatkan kualitas sumber daya manusia. Selain itu sekolah sebagai lembaga formal juga berusaha semaksimal mungkin dalam meningkatkan prestasi belajar peserta didik. Dalam rangka pembentukan karakter peserta didik sehingga beragama, beretika, bermoral, dan sopan santun dalam berinteraksi dengan masyarakat, maka pendidikan harus dipersiapkan, dilaksanakan, dan dievaluasi dengan mengintegrasikan pendidikan karakter di dalamnya. Sekolah dalam membentuk dan menanamkan nilaikarakter kepada peserta didik dapat melalui beberapa hal, diantaranya melalui pendekatan mata pelajaran, dan melalui kegiatan ekstrakurikuler.

Berdasarkan Undang-undang Sistem Pendidikan Nasional Nomor 20 Tahun 2003 pasal 37 ayat (1) menjelaskan bahwa pendidikan kewarganegaraan dimaksudkan untuk membentuk peserta didik menjadi manusia yang memiliki rasa kebangsaan dan cinta tanah air. Pendidikan karakter seharusnya membawa peserta didik ke pengenalan nilai secara kognitif, penghayatan nilai secara afektif, dan akhirnya ke pengamalan nilai secara nyata. Inilah rancangan pendidikan karakter (moral).

Pendidikan karakter secara terintegrasi di dalam mata pelajaran adalah pengenalan nilainilai, diperolehnya kesadaran akan terpentingnya nilai-nilai, dan penginternalisasi nilai-nilai ke dalam tingkah laku peserta didik sehari-hari melalui proses pembelajaran, baik yang berlangsung di dalam maupun diluar kelas pada semua mata pelajaran.

Pendidikan Kewarganegaraan (Civic Education) merupakan salah satu bidang kajian yang mengemban misi nasional untuk mencerdaskan kehidupan bangsa Indonesia melalui koridor "value-based education". PPKn merupakan program pendidikan yang sangat penting untuk upaya pembangunan karakter bangsa. Sebagai suatu program pendidikan yang amat strategis bagi upaya pendidikan karakter, PPKn perlu memperkuat posisinya menjadi "subjek pembelajaran yang kuat" (powerful learning area) yang secara kurikuler ditandai oleh pengalaman belajar secara kontekstual dengan cirri-ciri: bermakna (meaningful), terintegrasi (integrated), berbasis nilai (value based), menantang (challenging), dan mengaktifkan (activating).

Namun, permasalahan yang ada adalah praktek pendidikan dalam pembelajaran PPKn 
yang berlangsung di kelas pada saat ini hanyalah sebatas pendidikan yang berorientasi pada pencapaian tujuan kognitif saja. pendidikan kewarganegaraan lebih banyak mentransfer pengetahuan dan keterampilan tanpa disertai dengan internalisasi nilai yang terkandung dalam pengetahuan tersebut. Evaluasi yang digunakan juga lebih menekankan aspek kognitif, sehingga proses pembelajaran di sekolah lebih bersifat transfer pengetahuan, dari pada mengajarkan berfikir secara keilmuan dan internalisasi nilai melalui pemahaman sehingga kurang membentuk karakter peserta didik.

Kurang optimalnya pengembangan karakter, khususnya pada karakter bersahabat /komunikatif, pada pengaplikasiannya dikelas dalam proses pembelajaran belum mampu membangkitkan minat dan keterampilan mengemukakan pendapat siswa, karana pada pengaplikasiannya dikelas semua kegiatan pembelajaran hanya berfokus kepada guru sehingga siswa tidak terlalu tertarik dengan proses pembelajaran yang ada dikelas dan belum optimal dalam mengembangkan keterampilan mengemukan pendapatnya.

Pada kenyataanya di SMP Negeri 8 Makassar dalam proses pembelajaran siswa masih kurang aktif dalam pembelajaran, ) siswa kurang mampu mengemukakan pendapatnya, interaksi antara guru dan siswa, siswa dengan temannya kurang sopan dan kurang menghargai, dan siswa lebih terbiasa hanya mendengarkan penjelasan yang disampaikan oleh guru.

Berdasarkan Observasi awal maka dari itu peneliti mencoba mencari tahu tentang bagaimana Integrasi Pendidikan Karakter Pada Mata Pelajaran PPKn Untuk Mengembangkan Kemampuan mengemukakan pendapat Siswa di SMP Negeri 8 Makassar.

\section{TINJAUAN PUSTAKA}

\section{a. Integrasi Pendidikan Karakter}

Integrasi ini meliputi pemuatan nilainilai karakter ke dalam substansi mata pelajaran dalam materi dan kegiatan pembelajaran. Pendidikan karakter secara terintegrasi didalam mata pelajaran adalah pengenalan nilai-nilai, diperolehnya kesadaran akan terpentingnya nilai-nilai, dan penginternalisasi nilai-nilai ke dalam tinglah laku peserta didik sehari-hari melalui proses pembelajaran, baik yang berlangsung di dalam maupun diluar kelas pada semua mata pelajaran. Pada dasarnya kegiatan pembelajaran, selain untuk menjadikan peserta didik menguasai kompetensi,(materi) yang ditargetkan, juga dirancang untuk menjadikan peserta didik mengenal, menyadari/peduli, dan menginternalisasi nilai-nilai dan menjadikannya prilaku.

Menurut Sardiman (2011), Karakter merupakan suatu kumpulan karakteristik individu yang khas dalam berpikir, berperilaku, dan bertindak dalam hidup, bergaul, bekerjasama, maupun memecahkan masalah di lingkungannya. Dengan pendidikan karakter, diharapkan siswa menampilkan karakter tertentu yang sesuai dengan tujuan pendidikan nasional.

Nilai-nilai karakter yang diitetapkan Depdiknas dalam pendidikan karakter ada 18 yaitu: (1) religius, (2) jujur, (3) toleransi, (4) displin, (5) kerja keras, (6) kreatif, (7) mandiri, (8) demokratis, (9) rasa ingin tahu, (10)semangat kebangsaan, (11) cinta tanah air, (12) menghargai prestasi, (13) cinta damai, (14) bersahabat/komunikatif,(15) gemar membaca, (16) peduli lingkungan, (17) peduli sosial, (18) tanggung jawab.

Pada dasarnya kegiatan pembelajaran, selain untuk menjadikan peserta didik menguasai kompetensi, (materi) yang ditargetkan, juga dirancang untuk menjadikan peserta didik mengenal, menyadari / peduli, dan menginternalisasi nilai-nilai dan menjadikannya prilaku. Nilai-nilai yang sudah mulai terintegrasi pada semua mata pelajaran terutama pengembangan nilai toleransi, kerja keras, mandiri, demokratis, dan bersahabat/komunikatif.

Depdiknas (2010) dalam (Gunawan, 2012:2) menguraikan bahwa: Istilah berkarakter artinya memiliki karakter, memiliki kepribadian, berprilaku, bersifat, bertabiat, dan berwatak. Individu yang berkarakter baik atau unggul adalah seseorang yang berusaha melakukan halhal yang baik terhadap Tuhan Yang Maha Esa, dirinya, sesama, lingkungan, bangsa dan negara, serta dunia internasional pada umumnya dengan mengoptimalkan potensi (pengetahuan) dirinya dan disertai dengan kesadaran, emosi, dan motivasinya (perasaannya).

Hal tersebut juga senada dengan yang disebutkan oleh Aqib (2012: 40) menyebutkan bahwa berdasarkan kajian nilai-nilai agama, norma-norma sosial, peraturan/hukum, etika akademik, dan prinsip-prinsip HAM, telah teridentifikasi butir-butir nilai yang dikelompokkan menjadi nilai utama, yaitunilai- 
nilai perilaku manusia dalam hubungannya dengan Tuhan Yang Maha Esa, diri sendiri, sesama manusia, dan lingkungan serta kebangsaan.

\section{b. Pengintegrasian Pendidikan Karakter dalam Pembelajaran}

Merespons sejumlah kelemahan dalam pelaksanaan pendidikan akhlak danbudi pekerti, terutama melalui mata pelajaran PPKn,telah diupayakan inovasi pendidikan karakter. Inovasi tersebut adalah:

a. Pendidikan karakter dilakukan secara terintegrasi ke dalam semua matapelajaran. Integrasi yang dimaksud meliputi pemuatan nilai-nilai ke dalamsubstansi pada semua mata pelajaran dan pelaksanaan kegiatan belajarmengajar yang memfasilitasi dipraktikkannya nilai-nilai dalam setiap aktivitas pembelajaran di dalam dan di luar kelas untuk semua mata pelajaran.

b. Pendidikan karakter juga diintegrasikan ke dalam pelaksanaan kegiatan pembinaan kesiswaan.kesiswaan.

c. Selain itu, pendidikan karakter dilaksanakan melalui kegiatan pengelolaan semua urusan di sekolah yang melibatkan semua warga sekolah (Kemdiknas,2010).

Penegasan yang menyebutkan bahwa pendidikan berfungsi untuk mengembangkan pembinaan watak sebagai tujuan (output) penyelenggaraan pendidikan tentu akan berkaitan dengan seperangkat acuan nilai dan norma yang berkembang dan dijadikan pegangan oleh masyarakat.

Kandungan substansi yang tertuang dalam ketentuan pasal 1 ayat 1 UU No. 20 Tahun 2003 tentang sistem pendidikan nasional menyebutkan dengan jelas bahwa penyelenggaraan pendidikan nasional didasarkan pada orientasi dimensi nilai spiritual keagamaan, akar budaya nasional, responsif terhadap tuntutan dan tantangan perubahan jaman yang berkembang demikian cepat. Ketentuan lain yang terdapat dalam Bab II Pasal 3 menyebutkan pula bahwa Pendidikan nasional berfungsi mengembangkan kemampuan dan membentuk watak serta peradaban bangsa yang bermartabat dalam rangka mencerdaskan kehidupan bangsa, bertujuan untuk berkembangnya potensi peserta didik agar menjadi manusia yang beriman dan bertakwa kepada Tuhan Yang Maha Esa, berakhlak mulia, sehat, berilmu, cakap, kreatif, mandiri, dan menjadi warga negara yang demokratis serta bertanggung jawab.

Nilai sebagai sesuatu yang bermanfaat bagi kehidupan manusia dan norma yang berfungsi mengatur hak dan kewajiban secara benar dan bertanggungjawab tentu harus menjadi panduan bagi pembinaan peserta didik. Muara dari usaha tersebut ditegaskan dengan kalimat bahwa tujuan pendidikan nasionaluntuk mengembangkan segenap potensi yang dimiliki untuk menjadi manusia yang beriman dan bertakwa kepada Tuhan Yang Maha Esa, berakhlak mulia, sehat, berilmu, cakap, kreatif, mandiri dan menjadi warga negara yang demokratis serta bertanggung jawab.

\section{c. Hakikat Pendidikan Nilai}

Nilai sebagai sesuatu yang berharga, baik, luhur, diinginkan dan dianggap penting oleh masyarakat pada gilirannya perlu diperkenalkan pada anak.

Sanjaya (2007) mengartikan nilai (value) sebagai norma-norma yang dianggap baik oleh setiap individu. Inilah yang menurutnya selanjutnya akan menuntun setiap individu menjalankan tugas-tugasnya seperti nilai kejujuran, nilai kesederhanaan, dan lain sebagainya.

Upaya yang dapat dilakukan guru untuk mengintegrasikan pendidikan nilai di sekolah dapat dilakukan dengan menggunakan beberapa pendekatan diantaranya sebagai berikut:

a. Pendekatan Penanaman Nilai (inculcation approach) ialah suatu pendekatan yang menitikberatkan pada penanaman nilai-nilai sosial agar selanjutnya mampu terinternalisasi dalam diri siswa.

b. Pendekatan Perkembangan Kognitif. Pesertadidik mencapai kemampuan untuk membuat keputusan nilai berdasarkan tingkatan dan tahapan perkembangan moral.

c. Pendekatan Klarifikasi Nilai. Orientasi pendekatan klarifikasi nilai (values clarification approach) ialah memberi penekanan untuk membantu siswa mengkaji perasaan dan perbuatannya sendiri, kemudian secara bertahap kemampuan kesadaran mereka ditingkatkan terhadap nilai-nilai mereka sendiri. 
d. Pendekatan Pembelajaran Berbuat. Karakteristik pendekatan pembelajaran berbuat (action learning approach) berupaya menekankan pada usaha guru untuk memfasilitasi dengan memberikan kesempatan kepada siswa untuk melakukan perbuatan-perbuatan moral yang dilakukan baik secara perseorangan maupun secara berkelompok.

\section{d. Pendidikan \\ Pancasila Kewarganegaraan}

Pendidikan karakter serta penanaman nilai sangan terat kaitannya dengan mata pelajaran PPKn. Sutrisno (2017: 167) menyatakan bahwa "Pendidikan Pancasila dan Kewarganegaraan (PPKn) merupakan pendidikan yang memuat nilai-nilai karakter kebangsaan".

Fajar (2009: 9) menyatakan bahwa:

Pendidikan Kewarganegaraan adalah mata pelajaran yang memfokuskan pada pembentukan diri yang beragam dari segi agama, kultural, bahasa usia, dan suku, bangsa untuk menjadi warga negara Indonesia yang cerdas, terampil, dan berkarakter yang diamanatkan oleh Pancasila dan UUD 1945.

Jadi, dalam proses pembelajaran PPKn menuntut keterlibatan emosional, intelektual, dan sosial dari peserta didik dan guru sehingga nilai-nilai tersebut bukan hanya dipahami, akan tetapi kita menghayati, kemudian mengaplikasikannya dalam kehidupan seharihari. Berdasarkan pendapat-pendapat tersebut, dapat disimpulkan bahwa Pendidikan Pancasila dan Kewarganegaraan (PPKn) adalah pendidikan yang dilakukan untuk membentuk pribadi yang cerdas, terampil, demokratis, dan bertanggung jawab dalam bermasyarakat, berbangsa dan bernegara.

Secara rinci Fajar (2009) merumuskan bahwa tujuan mata pelajaran kewarganegaraan adalah sebagai berikut:

a. Berfikir secara kritis, rasional, dan kreatif dalam menanggapi isu kewarganegaraan.

b. Berpartisipasi secara bermutu dan bertanggung jawab, dan bertindak secara cerdas dalam kegiatan bermasyarakat, berbangsa dan bernegara.

c. Berkembang secara positif dan demokratis untuk membentuk pribadi yang berdasarkan pada karakter-karakter masyarakat Indonesia agar dapat hidup bersama dengan bangsa lainnya. d. Berinteraksi dengan bangsa yang lain dalam percaturan dunia secara langsung atau tidak langsung dengan memanfaatkan teknologi dan komunikasi.

Menurut Faturrohman \& Wuryandi (2011) dalam BSNP, ruang lingkup mata pelajaran Pendidikan Kewarganegaraan meliputi aspek-aspek sebagai berikut: "1) Persatuan dan Kesatuan bangsa; 2)Norma, hukum, dan peraturan; 3) Hak asasi manusia; 4) Kebutuhan warga negara; 5) Konstitusi Negara; 6) Kekuasaan dan politik; 7) Pancasila; dan 8) Globalisasi”.

\section{METODE}

Penelitian ini adalah jenis penelitian kualitatif dengan menggunakan pendekatan kualitatif. Demi menghindari kesalahpahaman dalam mendefinisikan dan memahami penelitian ini, maka calon peneliti memaparkan pengertian beberapa variabel yang dianggap penting, antara lain :

1. Upaya yang dilakukan tenaga pendidik dalam mengintegrasikan pendidikan karakter untuk meningkatkan kemampuan mengemukakan pendapat siswa adalah dengan menerapkan model atau metode pembelajaran yang tepat sesuai dengan materi pelajaran sehingga dapat melatih karakter siswa dan meningkatkan kemampuan mengemukakan pendapatnya.

2. Proses pengintegrasian pendidikan karakter dalam kegiatan pembelajaran untuk meningkatkan kemampuan mengemukakan pendapat siswa dilakukan dengan menerapkan model dan metode pembelajaran diantaranya:
a. Model Team Assisted Individualization (TAI)
b. Metode tanya jawab
c. Metode konvensional

3. Faktor yang mempengaruhi integrasi pendidikan karakter untuk meningkatkan kemampuan mengemukakan pendapat siswa yaitu suatu hal yang dapat memberikan pengaruh dalam pembentukan karakter siswa, baik yang bersifat mendukung maupun yang bersifat menghambat. berikut ini yang termasuk faktor pendukung integrasi pendidikan karakter:

a. Kegiatan yang sudah terprogram dengan baik dalam silabus dan RPP.

b. Sarana dan prasarana sekolah yang memadai. 
c. serta dukungan dan kerja sama yang baik antara guru dan orang tua siswa

Adapun yang menjadi faktor penghambat pengintegrasian pendidikan karakter untuk meningkatkan kemampuan mengemukakan pendapat siswa yaitu:

a. Kontrol sekolah yang terbatas

b. Kurangnya pemahaman tentang pendidikan karakter

c. Keberanian siswa untuk mengemukakan pendapatnya masi kurang

d. Adanya keterbatasan waktu dalam proses pembelajaran

Lokasi penelitian ini dilakukan di SMPN 8 Makassar. Adapun jenis dan sumber data dalam penelitian ini yaitu data primer dan data sekunder. Sumber data primer dalam penelitian ini antara lain:

(1) Kepala sekolah, (2) guru mata pelajaran PPKn (3) siswa. Sedangkan sumber data sekunder buku-buku, media massa, dan media cetak lainnya.

Teknik pengumpulan data yang digunakan dalam penelitian ini melalui tiga cara yaitu observasi, wawancara, dan dokumentasi.

Adapun analisis utama yang digunakan dalam penelitian ini adalah metode analisis kualitatif, yaitu mengidentifikasi, menemukan, dan menafsirkan berbagai temuan-temuan fakta yang terjadi di lapangan. Hasil analisis data selanjutnya dideskripsikan atau digambarkan sesuai dengan masalah dan tujuan yang ingin dicapai dalam penelitian. Langkah - langkah yang digunakan dalam menganalisis antara lain: (1) reduksi data, (2) penyajian data,(3) verivication

\section{HASIL DAN PEMBAHASAN}

\section{Upaya yang Dilakukan Tenaga Pendidik Untuk Mengintegrasikan Pendidikan Karakter Pada Mata Pelajaran PPKn Untuk Meningkatkan Kemampuan Mengemukakan Pendapat siswa}

Karakter bersahabat/komunikatif merupakan salah satu dari 18 karakter yang telah dirumuskan oleh pemerintah yang akan ditanamkan kepada siswa sebagai upaya membangun karakter bangsa. Tujuan penanaman karakter komunikatif pada siswa yaitu agar terciptanya susasana pergaulan yang nyaman, situasi yang mengundang, dan lingkungan yang menarik terutama selama proses pembelajaran.

Adapun upaya yang dilakukan guru dalam mengintegrasikan pendidikan karakter untuk meningkatkan kemampuan mengemukakan pendapat siswa dalah dengan menerapkan model atau metode pembelajaran yang tepat.

Berdasarkan dari hasil observasi dan hasil wawancara dapat disimpulkan bahwa guru PPKn di SMP Negeri 8 makassar menerapkan model atau metode pelajaran diantaranya : (1) Model Model Team Assisted Individualization (TAI) (2) Metode tanya jawab (3) Metode konvensional.

\section{Proses Integrasi Pendidikan Karakter Pada Mata Pelajaran PPKn Untuk Meningkatkan Mengemukakan Pendapat Siswa}

Berdasarkan dari hasil observasi dan hasil wawancara dapat disimpulkan bahwa Pengintegrasian pendidikan karakter pada proses pembelajaran PPKn dengan model atau metode pembelajaran sebagai berikut:

1. Team Assisted Individualization (TAI)

Model pembelajaran ini merupakan model pembelajaran kelompok yang didalamnya terdapat peer tutoring artinya bantuan siswa ke siswa yang lain, adapun langkah-langkah dari model pembelajaran Team Assisted Individualization (TAI) yaitu:

a. Team. Pada langkah ini guru membentuk kelompok-kelompok yang terdiri dari $4-5$ siswa, secara heterogen.

b. Teaching Group. Pada langkah ini guru memberikan materi singkat menjelang pemberian tugas kelompok.

c. Student Creative. Pada langkah ini guru perlu menekankan dan menciptakan persepsi bahwa keberhasilan setiap siswa (individu) ditentukan oleh keberhasilan kelompoknya.

d. Team Study. Pada langkah ini siswa belajar bersama dengan mengerjakan LKS / tugas yang diberikan dalam kelompoknya.

e. Test. Pada langkah ini guru memberikan tes berdasarkan fakta yang diperoleh siswa, misalnya dengan memberikan evaluasi, kuis dan sebagainya.

f. Team Score and Team Recognition. Pada langkah ini guru memberikan skor pada hasil kerja kelompok dan memberikan 
"gelar" penghargaan terhadap kelompok yang berhasil.

2. Metode tanya jawab

Metode tanya-jawab merupakan suatu teknik untuk memberikan motivasi kepada siswa agar bangkit pemikirannya untuk bertanya atau menjawab pertanyaan dari guru, sehingga terjadi proses tanya-jawab untuk bertukar pengetahuan dan informasi. Adapun langkah-langkah dari metode tanya jawab yaitu:

a. Menjelaskan kepada siswa tujuan pembelajaran khusus yang akan dicapai dalam pembelajaran (TPK).

b. Mengkomunikasikan penggunaan metode tanya jawab.

c. Guru memberikan permasalahan sebagai bahan apersepsi.

d. Guru mengajukan pertanyaan keseluruh kelas berdasarkan materi pelajaran yang sedang dibahas.

e. Guru harus memberikan waktu yang cukup kepada siswa untuk memikirkan jawaban dari pertanyaan.

f. Tanya jawab harus berlangsung dalam suasana tenang, dan bukan dalam suasana yang tegang dan penuh persaingan yang tak sehat.

g. Pertanyaan dapat ditujukan pada seorang siswa atau seluruh kelas.

h. Pertanyaan ada beberapa macam, yaitu pertanyaan pikiran, pertanyaan mengungkapkan kembali pengetahuan yang dikuasai, dan pertanyaan yang meminta pendapat, saran, sikap, serta pertanyaan yang hanya mengungkapkan fakta-fakta saja.

\section{Motode konvensional}

Metode konvensional merupakan metode dimana siswa lebih banyak mendengarkan penjelasan oleh guru dikelas. Variasi yang dilakukan dengan tanya jawab dan pemberian tugas. Pertanyan-pertanyaan atau tugas-tugas yang disampaikan hanya pada tingkat pemahaman atau aplikasi.Tidak sampai pada taraf berfikir tingat tinggi atau pemecahan masalah. Adapun langkah-langkah dari metode konvensional yaitu:

a. Menyampaikan tujuan pelajaran yang ingin dicapai.

b. Menyajikan informasi, atau memberikan materi secara bertahap demi tahap.

c. Mengecek pemahaman dan memberikan umpan balik. d. Memberikan tugas lanjutjan untuk dikerjakan di rumah.

4. Faktor Pendukung dan Penghambat Implementasi Pendidikan Karakter Untuk Meningkatkan Kemampuan Mengemukakan Pendapat Siswa

a. Faktor pendukung

Kesimpulan yang dapat ditarik dari hasil wawancara bersama guru PPKn di SMP Negeri 8 Makassar tentang faktor pendukung implementasi pendidikan karakter untuk meningkatkan kemampuan mengemukakan pendapat siswa yaitu:

1. Sarana dan prasana sekolah yang memadai, dan juga ketersediaan alat dan media pembelajaran yang dapat digunakan guru untuk menunjang kegiatan pembelajaran.

2. Kemampuan guru dalam memilih model atau metode yang tepat. Model atau metode pembelajaran yang tepat dapat melatih dan membiasakan siswa untuk mengembangkan karakternya.

3. Koordinasi yang baik yang terjalin antara guru dan orang tua siswa. Artinya bukan hanya guru sebagai satu-satunya penanggung jawab atas keberhasilan pembentukan karakter siswa, akan tetapi terjalin kerja sama yang baik antara guru dan orang tua untuk saling membantu dan mengawasi anak-anaknya.

b. Faktor penghambat

1. Kontrol sekolah yang terbatas, artinya ketika sudah berada diluar sekolah itu merupakan tanggung jawab orang tua dan lingkungan dimana siswa berada.

2. Kurangnya pemahaman tentang pendidikan karakter dalam pelaksanaannya.

3. Pada saat proses pembelajaran masih ditemukan siswa yang malu untuk mengemukakan pendapatnya, meskipun telah ditawari oleh guru untuk menanggapinya.

4. Waktu, artinya membutuhkan banyak waktu untuk melatih semua siswa untuk melatih keterampilan mengemukakan pendapatnya sedangkan waktu pembelajaran terbatas, ditambah lagi dengan jumlah siswa yang banyak dimana setiap kelasnya terdapat 36 siswa. 
Pembahasan

1. Upaya Pengintegrasian Pendidikan Karakter Guru PPKn Dalam Meningkatkan Keterampilan Mengemukakan Pendapat di SMP Negeri 8 Makassar

Pendidikan karakter bukanlah pelajaran hafalan melainkan pendidikan perilaku yang terbentuk melalui pembiasaan, butuh waktu dan komitmen pihak sekolah dan guru sebagi ujung tombak dalam pembentukan dan pengimplementasian pendidikan karakter. Perilaku atau karakter siswa bisa tercermin dari proses interaksi yang mereka lakukan setiap hari baik itu di ruang lingkup sekolah, keluarga maupun masyarakat. Karakter komunikatif adalah tindakan perilaku yang memperlihatkan rasa senang berbicara, bergaul, dan bekerja sama dengan orang lain melalui komunikasi yang santun sehingga tercipta kerja sama secara kolaboratif dengan baik antara pesera didik dengan guru maupun antara siswa dengan siswa dalam pembelajaran PPKn sehingga keterampilan mengemukakan pendapat pada siswa dapat dilatih dan dikembangkan.

Upaya pengintegrasikan karakter kedalam proses pembelajaran pendidikan di desain secara terintegrasi oleh guru PPKn dengan menentukan model dan metode pembelajaran yang tepat pada saat proses pembelajaran berlangsung seperti yang dilakukan oleh guru PPKn di SMP Negeri 8 Makassar. Untuk meningkatkan kemampuan mengemukakan pendapat siswa guru menerapkan model dan metode pembelajaran yang sesuai dengan materi pelajaran.

\section{Proses Pengintegrasian Pendidikan} Karakter yang Dilakukan Guru PPKn Dalam Meningkatkan Keterampilan Mengemukakan Pendapat di SMP Negeri 8 Makassar

1. Menerapkan model pembelajaran kooperatif Team Assisted Individualization.

Model pembelajaran ini merupakan model pembelajaran kelompok untuk berdiskusi, dimana siswa dapat berkomunikasi secara langsung dengan teman kelompoknya, memberi atau menjawab pertanyaan serta menyampaikan hasil diskusi. Pengaplikasian model pembelajaran ini diharapkan dapat melatih karakter siswa seperti halnya sifat saling meghargai antar sesama, melatih kedisplinan, bertanggung jawab, keberanian untuk mengemukakan pendapat, serta melatih siswa untuk berfikir kritis.

2. Menerapkan metode tanya-jawab

Metode tanya jawab juga dapat diartikan sebagai suatu cara mengajar yang memungkinkan terjadinya komunikasi secara langsung yang bersifat two way traffic sebab pada saat yang sama terjadi dialog antara siswa dan guru. Guru bertanya siswa menjawab atau siswa bertanya guru menjawab. Dalam komunikasi ini terlihat adanya hubungan timbal balik secara langsung antara guru dan siswa yang diharapkan mampu meningktkan karakter komunikatif dalam bentuk keterampilan mengemukakan pendapat.

3. Menerapkan metode konvensional

Model konvensional dimana siswa lebih banyak mendengarkan penjelasan oleh guru dikelas. Variasi yang dilakukan dengan tanya jawab dan pemberian tugas. Pertanyanpertanyaan atau tugas-tugas yang disampaikan hanya pada tingkat pemahaman atau aplikasi. Tidak sampai pada taraf berfikir tingat atau pemecahan masalah. Guru mengecek pemahaman dan memberikan umpan balik dengan meberikan pertnyaan kepeda siswa, kemudian meminta siswa yang lain untuk memberikan tanggapan, disinilah guru melatih kememkuan mengemukakan perndapat siswa.

3. Faktor Pendukung dan Penghambat Implementasi Pendidikan Karakter Untuk Mengemukakan Pendapat Siswa

a. Faktor pendukung

Setiap proses pelaksanaan pendidikan karakter baik dalam kegiatan pembelajaran khususnya dalam hal keterampilan mengemukakan pendapat tidaklah lepas dari faktor-faktor pendukung, dari kenyataan tersebut menunjukkan keberhasilan pelaksanaan pendidikan karakter di SMP Negeri 8 Makassar. Adapun faktor pendukungnya adalah sebagai berikut:

1. Kegiatan yang sudah terprogram dengan baik, artinya guru-guru PPKn yang ada di SMP Negeri 8 Makkasasar dalam mengimplementasikan pendidikan 
karakter, terlihat jelas pada bagain silabus dan RPP yang digunakan oleh guru dalam pembelajaran dikelas.

2. Sarana dan prasarana dan sumber daya manusia yang ada di SMP Negeri 8 Makassar sangatlah membantu dalam pelaksanaan pendidikan karakter di sekolah.

3. Orang Tua, kondisi lingkungan yang memadai dan dukungan dari seluruh orang tua siswa yang ada di SMP Negeri 8 Makassar.

b. Faktor Penghambat

1. Kontrol sekolah yang terbatas, artinya ketika sudah berada diluar sekolah itu merupakan tanggung jawab orang tua dan lingkungan siswa berada.

2. Kurangnya pemahaman tentang pendidikan karakter dalam pelaksanaannya.

3. Pada saat pembelajaran masih ditemukan siswa yang malu untuk mengemukakan pendapatnya, meskipun telah ditawari oleh guru untuk menanggapinya.

\section{SIMPULAN DAN SARAN}

Berdasarkan temuan, kajian dan pemaparan peneliti tentang Integrasi Pendidikan Karakter Pada Mata Pelajaran PPKn untuk Meningkatkan Kemampuan Mengemukakan Pendapat Siswa di SMP Negeri 8 Makassar, dapat ditarik beberapa kesimpulan sebagai berikut: (1) Upaya yang dilakukan tenaga pendidik untuk mengintegrasikan pendidikan karakter pada mata pelajaran PPKn untuk mengembangkan kemampuan mengemukakan pendapat siswa di SMP Negeri 8 Makassar adalah dengan menerapkan model dan metode pembelajaran yang menarik serta dapat melatih siswa untuk mau dan berani mengemukakan pendapatnya agar tercipta situasi dan kondisi yang menyenangkan di dalam kelas selama proses belajar mengajar berlangsung. Selain itu, didalam kegiatan pembelajaran siswa dilatih dan dibiasakan untuk mengengembangkan karakternya; (2) Proses pengintegrasian pendidikan karakter yang dilakukan oleh guru mata pelajaran PPKn untuk mengembangkan kemampuan mengemukakan pendapat siswa di SMP Negeri 8 makassar adalah menerapkan model dan metode pembelajaran diantaranya : 1) Menerapkan model pembelajaran kooperatif Team Assisted Individualization 2) Menerapkan metode tanya-jawab 3) Menerapkan metode konvensional; (3) Faktor Pendukung dan Penghambat Implementasi Pendidikan Karakter Untuk Mengemukakan Pendapat Siswa di SMP Negeri 8 Makassar. Faktor pendukung Kegiatan yang sudah terprogram dengan baik dalam silabus dan RPP, sarana dan prasarana yang memadai, serta dukungan dan kerja sama yang baik antara guru dan orang tua siswa. Faktor penghambat pengintegrasian pendidikan karakter adalah kontrol sekolah yang terbatas, kurangnya pemahaman tentang pendidikan karakter, keberanian siswa untuk mengemukakan pendapatnya masi kurang, dan adanya keterbatasan waktu dalam kegiatan pembelajaran.

Berdasarkan dari kesimpulan di atas, maka peneliti dapat memberikan saran demi kemajuan pendidikan karakter adalah: (1) Untuk tenaga pendidik, dipandang penting untuk mengintegrasikan pendidikan karakter dalam proses pembelajaran dengan cara menggunakan model atau metode pembelajaran yang lebih inovatif mengundang minat belajar siswa, serta mudah di pahami oleh para siswa; (2) Pendidikan karakter diharapkan dapat diterapkan dalam setiap lapisan pendidikan karena mampu menguatkan mutu pendidikan di era modernisasi saat ini; (3) Untuk Kementerian Pendidikan dan Kebudayaan sebaiknya memperhatikan tentang pembelajaran pendidikan karakter agar kiranya disetiap jenjang pendidikan formal serta dapat diusulkan untuk dijadikan sebagai bahan pembelajaran yang diwajibkan di setiap sekolah di seluruh Indonesia; (4) Lingkungan sekolah adalah faktor yang berpengaruh terhadap pembentukan karakter agar lebih ditingkatkan kedisiplinannya didalam menjaga lingkungan sekolah perlu adanya kata-kata bijak untuk siswa agar lebih memotivasi siswa di dalam menjaga lingkungan sekolah

\section{DAFTAR RUJUKAN}

Aqib, Z. 2012. Pendidikan Karakter Di Sekolah (Membangun Karakter Dan Kepribadian Anak). Bandung: Yrama Widya.

Fathurrohman dan Wuryandani, Wuri. 2011. PembelajaranPKn di Sekolah. Yagyakarta: NuhaLitera. 
Phinisi Integration Review. Vol 3(1) Februari 2020

Fajar,Anie.2009. Portofoliodalampembelajaran IPS. Bandung: PT RemajaRosdakarya Offset.

Gunawan, H. 2012. Pendidikan Karakter (Konsep dan Implementasi). Bandung:Alfabeta.

Kementrian Pendidikan Nasional. 2010. Desain Induk Pendidikan Karakter, Jakarta.

Perpres Nomor 87 Tahun 2017 Tentang Penguatan Pendidikan Karakter.

Sardiman AM. 2011. "Praktik IPS sebagai Wahana Pendidikan Karakter". Dalam Darmiyati Zuchdi dkk (ed.). Pendidikan Karakter dalam Perspektif Teori dan Praktik.Yogyakarta: UNY Press. Cet. I

Sanjaya, Wina. 2007. Kurikulum dan Pembelajaran Sekolah Dasar. Bandung: SPs UPI.

Sutrisno.2017. Implementasi Pendidikan Anti korupsi pada Mata Pelajaran PPKn Berbasis Project citizen di SMA.Jurnal Civics.Vol.14.no.2.Jurnal Civics.Vol.14.no.2

(https://journal.uny.ac.id/index.php/civic s/, Diakses31Desember 2019).

Undang-Undang Nomor 20 Tahun 2003 Tentang Sistem Pendidikan Nasional. 